\title{
Features of Flora Ridge Malguzar
}

\author{
D. E. Azimova \\ Jizzakh State Pedagogical Institute
}

\begin{abstract}
The article is devoted to peculiarities of flora ridge Malguzar that are associated with the geographical location of the area. In Botanical-geographic range Malguzar refers to Kuhistan mountainous central Asian district of the province, except the Western part of the ridge, which is part of the Nurata district. As a result, the flora of Malguzar in its composition and structure is a transition between floors of the Turkestan and Nuratau ridge.
\end{abstract}

Keywords: flora, Botanical and geographical zoning, endemic, systematic analysis, geographical analysis

\section{Introduction}

Ridge Malguzar is one of the most original and interesting in Botanical and geographical regions of Central Asia. It constitutes the North Western spur of the Turkestan range stretches about $80 \mathrm{~km}$ and a width of about $30 \mathrm{~km}$, its maximum altitude is $2,620 \mathrm{~m} \mathrm{n.m}$. According to the current scheme of Botanical-geographic zoning of mountainous Central Asia [1, 2, 3, 4], Malguzar (except the Western tip) and the Northern slope of the Turkestan ridge are part Kuhistan mountainous central Asian province.

Within Uzbekistan, located Western part of the County with two Botanical-geographical areas - North Turkestan and Urgut. Strong segmentation and the complexity of the terrain, a large amplitude of heights, a wide range of soil and climatic conditions cause a great variety of flora and vegetation. Here are the semi-arid variant of all the foothill and mountain genera of landscapes in the Central Asia and most of the mountain florocoenotypes. Compared with Western Tien Shan, the boundaries of vegetation zones are slightly shifted upwards. Juniper forests of Kuhistan, particularly in the Turkestan ridge, at its poletnost and floral wealth have no analogues in Central Asia. According to R. V. Camelin [1, 2, 3], flora of the district includes Kuhistan 2080 species.

The Uzbek part of the Turkestan range and mountain Malguzar (except the Western tip) are to the NorthTurkestan district Kuhistan district. District to date is poorly understood and a full synopsis of flora that is missing. The first floristic summary was a list of 368 species of vascular plants, published by M. G. Popov and N. In. Androsov [5]. In the monograph of E. M. Demarini [6] for the Western part of the Turkestan range specified 1139 species. In the Zaamin nature reserve that has an area of 26.8 thousand ha and covering only the upper two zones of vegetation, was 1192 species of plants belonging to 530 genera and 103 families [7]. This allows us to assess the flora of the North-Turkestan district not less than 1400-1500 species.

Western extremity of the ridge Malguzar refers to Nurata Nurata district of the County, which also includes the Nuratau mountains with adjacent ostanovili ranges. In relation to floristic district is well studied. A list compiled by V. R. Kamelin for Nurata mountains [1], 1172 includes 475 species from genera and 84 families of vascular plants. Species composition of the flora of the Nurata district has a high degree of similarity with the flora of Kuhistan (more than $80 \%$ of the total species). At the same time, because of its specific geographical position, geological history and floragenesis is more originality, contrast and rather high rate of endemism $(5.3 \%)$.

In the herbarium of the funds TASH, with a large abundance of material from the Western part of the Turkestan range and the Nuratau mountains, samples from the ridge Malguzar represented. Until recently, Malguzar remained one of the floristically poorly studied areas of Uzbekistan.

The study of the flora ridge Malguzar is within the public application of the project "Botanical-geographical zoning and the creation of a single database on plant diversity of Uzbekistan" (A7-FA-ON-19606) and the innovation project "Cadastre of the genetic Fund of Uzbekistan. Part II. Jizzakh and Samarkand region. Vascular plants, vertebrate animals" (I5-FA-ON-17440).

As a result of our routing research 2011-2013, as well as learning materials TASH for ridge Malguzar currently well established in 1152 species of plants. We do not believe this final figure, however, the results obtained allow to characterize the main features of the studied flora.

Structure of the flora typical of mountainous Middle Asia. In particular, the leading role belongs to the Asteraceae (155 species), Fabaceae (132 species), Poaceae (123), Brassicaceae (62), Lamiaceae (60), Apiaceae (55), Caryophyllaceae (44), Boraginaceae (39), Scrophulariaceae and Ranunculaceae (37), Rosaceae (36), Liliaceae and Polygonaceae (25), Alliaceae (23), Rubiaceae (18), Chenopodiaceae (17 species). 10 leading families of the flora of Malguzar includes 744 species $(64,3 \%$ of the flora). The first three polymorphs of the families Asteraceae, Fabaceae and Poaceae combines 410 species $(35.6 \%$ of the flora). The leading position of these three families is typical for almost all local floras of mountainous Central Asia. Spectrum of the leading families of the ridge Malguzar largely similar to the structure of Flora Zaamin nature reserve and the basin of the Zeravshan river, which also apply to Kuhistan and floors with neighboring Botanical and geographical regions of the Nurata mountains, Syr Darya Karatau, South-Western Tien-Shan [1, 7, 8, 9].

The largest genera in the flora of Malguzar are Astragalus L. (62 species), Allium L. (23 species), Gagea Salisb. (20),

\section{Volume 6 Issue 12, December 2017}




\section{International Journal of Science and Research (IJSR) \\ ISSN (Online): 2319-7064}

Index Copernicus Value (2016): 79.57 | Impact Factor (2015): 6.391

Cousinia Cass. (18), Ranunculus L. and Veronica L. (14), Artemisia Less. (13), Ferula L. and Euphorbia L. (12), Poa L. (11), Scutellaria L. and Valerianella Mill. (9), Silene L., Oxytropis DC., Piptatherum P. Beauv., Vicia L., Polygonum L., Chenopodium L. and Carex L. (8), Eremurus M. Bieb., Rumex L., Potentilla L. and Rosa L. (7). A generic spectrum of the flora also shows the affiliation of the flora of Malguzar to East ancient Mediterranean, in particular, mountainous central Asian flora.

A significant number of species of Carex, Ranunculus, Poa, Veronica shows the presence in the study area environmental conditions for the growth of mesophilic boreal elements.

A prominent role in the flora and vegetation of Malguzar played by the representatives of the genera Chenopodium, Polygonum, Rumex and other types with polyregional type of area (Acroptilon repens (L.) DC., Anagallis arvensis L., Artemisia annua L., A. vulgaris L., Centaurea solstitialis L., Convolvulus arvensis L. Conyza canadensis (L.) Cronq., Descurainia sophia (L.) Webb. ex Prantl., Echium biebersteinii Lacaita, Erigeron acris L., Galium aparine L., Hypericum perforatum L., Medicago sativa L., Myosotis refracta Boiss., Onopordum acantum L., Reseda lutea L., Setaria viridis (L.) P. Beauv., Torilis arvensis (Huds.) Link Turgenia latifolia (L.) Hoffm., Verbena officinalis L., Xanthium spinosum L., and etc.), which is an indicator of anthropogenic disturbance of ecosystems in the region.

Features of the flora of the study area is determined by its location at the junction of Kuhistan and Nuratau floristic district. As a result, the flora of Malguzar in its composition and structure is a transition between floors of the Turkestan and Nuratau ridge. In particular, this circumstance is associated low rate of endemism in the flora of Malguzar. The endemic element in the flora ridge Malguzar represented a very small number of species. Narrow endemics ridge Malguzar there are only 3 (Allium levichevii F. O. Khass., Cousinia malguzarica Juz., Oxytropis kamelinii Vass.). They are all young progressive types. 5 species of Malguzar are endemic to the North of the Turkestan district (Astragalus belolipovii Kamelin ex F. O. Khass. et N. Sulajm., Russanovii A. F. O. Khass. et Esankulov, Cousinia horridula Juz., C. chlorantha Kult., Scutellaria schachristanica Juz.). More numerous subendemic Kuhistan (Allium alexejanum Regel, Jurinea helichrysifolia Popov ex Iljin, Oxytropis capusii Franch., O. sarawschanica Gontsch. ex Vassilcz. et B. Fedtsch. etc.) and especially the Nuratau-Kuhistan species (Cupuliferum Regel Allium, Astragalus knorringianus Boriss., Cousinia dshisakensis Kult., C. pseudodshisakensis Tschern. et Vved., C. dubia M. Pop., C. haesitabunda Juz., The genus Dracocephalum nuratavicum, Ferula dshizakensis Korov., Hedysarum nuratense Popov, Nanophyton saxatile Botsch., Oxytropis tachtensis Franch., Phlomis linearifolia Zak., Pseudoclausia olgae (Regel et Schmalh.) Botsch., Seseli korovinii Schischk., Silene paranadena Bondar. et Vved., Tulipa affinis Z. Botsch. etc.). This fact emphasizes the transitional character of the studied flora.

Overall, in the flora ridge Malguzar is dominated by species belonging to the Pamir-Alai, mountainous Badakshan and anciently Mediterranean lasses of habitats. In the vegetation of the highland and lowland zones, play a leading role zapadnotekhasskaya-Pamir-Alai species (Ranunculus mindshelkensis B. Fedtsch., $R$. pinnatisectus Popov, Dianthus tetralepis Nevski ex Schischk., Megacarpaea orbiculata B. Fedtsch., Amygdalus bucharica Korsh., Astragalus bactrianus Fisch., A. sewerzowii Bunge, Ferula penninervis Regel et Schmalh., Artemisia sogdiana Bunge, Lepidolopha C. komarovii Winkl., Perovskia angustifolia Kudr., Eremurus sogdianus (Regel) Franch. etc.), as well as Western Pamir Alai and Pamir-Alai species (Astragalus Bunge nobilis ex B. Fedtsch., Ferula kokanica Regel et Schmalh., Jurinea maxima C. Winkl., J. trautvetteriana Regel et Schmalh., Mentha pamiroalaica Boriss., Thapsoides Bunge Phlomis, Phlomoides kaufmanniana (Regel) Adyl., R. Kam. et Machmedov, Fritillaria olgae Vved., Gagea hissarica Lipsky, Eremurus kaufmanii Regel, Eremurus olgae Regel, Piptatherum pamiroalaicum (Grig.) Roshev.). Widely represented mountainous Badakshan and Kopetdag- mountainous Badakshan species (Anemone petiolulosa Juz., Delphinium batalinii Huth., Ranunculus sewerzovii Regel, Amygdalus spinosissima Bunge, Astragalus wrist Bunge, A. lasiosemius Boiss., Acer pubescens Franch, Bunium chaerophylloides (Regel et Schmalh.) Drude., Artemisia tenuisecta Nevski, Regel Eremurus regelii, etc.).

Also a significant proportion of the Iranian-Central Asian, Iranian-Turanian and Iranian- in Himalayan elements (Delphinium semibarbatum Bien. ex Boiss., Glaucium elegans Fisch. et C. A. Mey., Papaver pavoninum Schrenk, Roemeria refracta (Stev.) DC., Acanthophyllum pungens (Bunge) Boiss., Crambe kotschyana Boiss., Cotoneaster nummularis Fisch. et C. A. Mey., Crataegus pontica C. Koch., Astragalus campylotrichus Bunge, Onobrychis chorassanica Bunge, Vicia subvillosa (Ledeb.) Boiss., Pistacia vera L.).

Very variously represented in the flora of Malguzar ancient Mediterranean species, including many of the dominant and subdominant vegetative cover (Anisantha sterilis (L.) Nevski, Avena fatua L., Boissiera by (Sol.) Nevski, Bromus danthoniae Trin. ex C. A. Mey., Bromus scoparius L., Hordeum bulbosum L., H. leporinum Link, H. spontaneum C. Koch, Poa bulbosa L., Ceratocephala falcata (L.) Reg., Thalictrum isopyroides C. A. Mey., Arenaria leptoclados (Reichenb.) Guss., Holosteum umbellatum L., Pleconax conoidea (L.) Šourková, Rosa canina L., Glycyrrhiza glabra L. Medicago minima (L.) Bartal. etc.). These types of leaders mainly in the foothill and low mountain zones.

In General, the flora ridge Malguzar has a greater resemblance to the flora of the Western part of the Turkestan range than the Nurata mountains. Differences in the species composition of the flora of Malguzar and the Western part of the Turkestan range, on the one hand, explains the relatively low height of Malguzar, which in its flora no high mountains and some mountain species (Angelica brevicaulis (Rupr.) B. Fedtsch., Astragalus chionanthus Popov, Carex melanantha C. A. Mey., Rhodiola gelida Schrenk, etc.). On the other hand, in the Western extremity of Malguzar come some endemic Nurata district, including Anura pallidivirens (Kult.) Tscherneva is the representative of the Nurata

\section{Volume 6 Issue 12, December 2017}




\section{International Journal of Science and Research (IJSR) \\ ISSN (Online): 2319-7064 \\ Index Copernicus Value (2016): 79.57 | Impact Factor (2015): 6.391}

mountains endemic monotypic genus. A number of species characteristic of the foothills plains, foothills and low mountains are common for Malguzar and Nuratau mountains, but none on the Turkestan ridge (Astragalus striatellus Pall., Consolida leptocarpa Nevski etc. Including some rare species listed in the Red Book of Uzbekistan (Allium isakulii R. M. Fritsch et F. O. Khass., Astragalus kelleri Popov, Lagochilus inebrians Bunge, etc.). In addition, Malguzar found interesting species with a disjunctive distribution area is missing as in the Nuratau mountains and the Turkestan ridge (Euphorbia sororia Schrenk, Pyrus korshinskyi Litv., Sedum pentapetalum Boriss.).

Therefore, flora ridge Malguzar is a typical moderately rich flora within mountainous central Asian province. Analysis of the species composition of the flora shows that in Botanical and geographical respect, Malguzar refers to the North-Turkestan district Kuhistan mountainous central Asian province.

\section{References}

[1] Kamelin, R. V. Flora Of The Syr-Darya Karatau. Leningrad: Nauka, 1990. 146 P (in Russian).

[2] Kamelin R. V. close genetic analysis of natural flora in mountainous Middle Asia. L., 1973. 365 p (in Russian).

[3] Kamelin R. V. Kuhistan district of mountainous Middle Asia. Botanical-geographical analysis. L.: Nauka, 1979. $166 \mathrm{p}$ (in Russian).

[4] Tojibaev K. Sh., Besco N. Yu., Popov V. A. On the project of the Botanical-geographic zoning of Uzbekistan // Bikila-chillin today materials of the Republican scientific-practical conference. - Gulistan, 2012. - S. 610 (in Russian).

[5] Popov M. G. Androsov, N. In. The vegetation of Guralash reserve and Zaaminsky forest cottage. Tashkent: Publishing house of the Committee of science of the Uzbek SSR, in 1937. 39 p (in Russian).

[6] Demurina E. M. Vegetation of the Western part of the Turkestan range and its North-Western spurs. Tashkent: FAN, 1975. 189 P (in Russian).

[7] Esankulov A. S. flora of the Zaamin state reserve: abstract. Diss. kand. Biol. Sciences. Tashkent, 2012. 19 (in Russian).

[8] Zakirov Z. K. flora and vegetation of the basin of the Zeravshan river. Part 2. Synopsis of flora. Tashkent: Izdvo an UzSSR, 1962. 446 p (in Russian).

[9] Tojibaev K. S. Flora of South-Western Tien-Shan (in the territory of the Republic of Uzbekistan). Tashkent: Fan, 2010. 98 p (in Russian). 